\title{
The Master's Degree in the Modern Languages since 1966
}

DOUG STEWARD

The story of the master's degree in English and foreign languages since 1966 is most dramatically a story about women's access to areas of study traditionally dominated by men and more generally a story about how economic shifts influence students' degree decisions. Statistics on how many master's degrees in English and foreign languages were conferred between 1966 and 2001, disaggregating the numbers for gender, provide a somewhat misleading starting point. Figures 1 and 2 show the arc of these degree conferrals, humped on the years 1970-71 and 1994-95. Excluding these humps, the overall number of master's degrees granted in the field of English has remained almost constant over the last three and a half decades, wavering around 6,000 degrees per year: 6,279 degrees in 1966 and 5,496 in 2001, a decline of $12.5 \% .{ }^{1}$ In foreign languages, the decline has been more pronounced, with degree conferrals wavering around 3,000 per year: 3,402 in 1966 and 2,197 in 2001, a decline of 35.4\%. To represent the decline in degree conferrals in these fields solely in terms of numbers of degrees, however, disguises the fact that these fields' percentage shares of all master's degrees granted have slipped markedly. English's share slipped to $1.18 \%$ in 2001 , less than a third of its $4.46 \%$ share in 1966; foreign languages accounted for only $0.47 \%$ in 2001 , a fifth of their $2.42 \%$ share in 1966 (fig. 3). In other words, as a share of all master's degrees granted, master's degrees

The author is Assistant Director of MLA English Programs and the Association of Departments of English. A version of this article appeared in the Winter 2004 issue of the ADE Bulletin. 
in English have declined by $72 \%$ in the past three and a half decades, those in foreign languages by $80 \%$. If these fields had maintained their 1966 percentage share of all master's degrees, in 2001 there would have been over 20,000 master's degrees in English and over 11,000 in foreign languages.

A variety of causes from outside the profession help explain the numerically anomalous 1970-71 high of 4,837 foreign language and 10,622 English degrees and the subsequent decades-long percentage-share decline.

\section{FIGURE 1}

Master's Degrees in English, by Gender, 1966-98, 2000-01

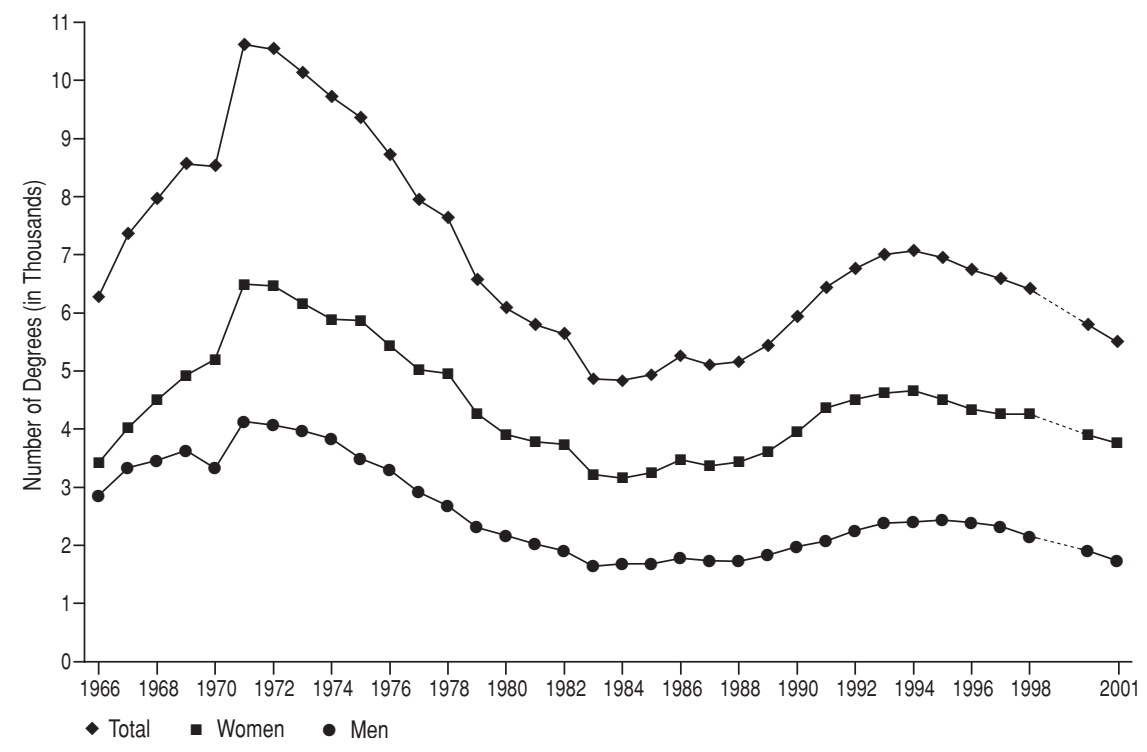

FIGURE 2

Master's Degrees in Foreign Languages, by Gender, 1966-98, 2000-01

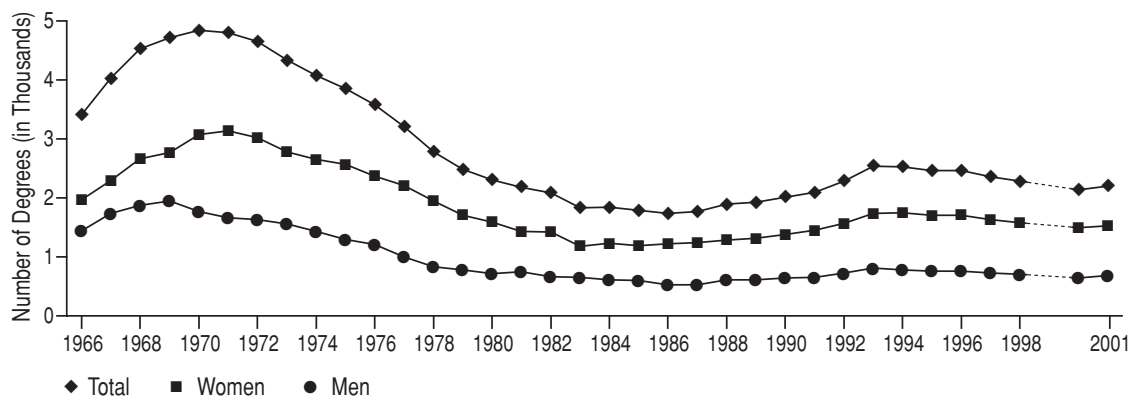


FIGURE 3

Master's Degrees in English and Foreign Languages per

Hundred of All Master's Degrees Awarded, 1966-98, 2000-01

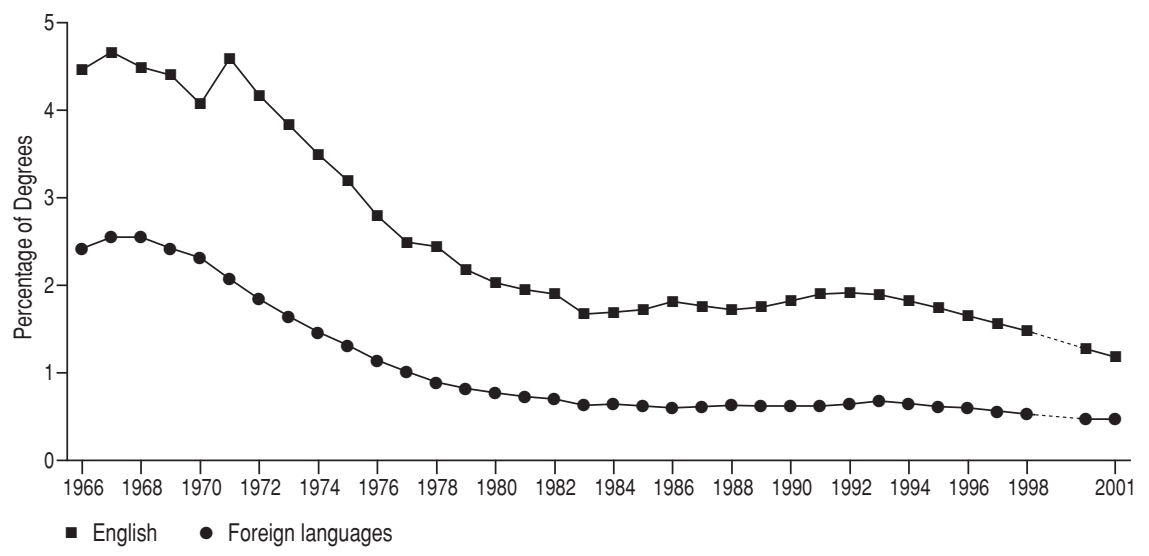

At the national level, the United States economy was in full expansion mode after World War II up to the early 1970s, when stagflation called into question the sustainability of such expansion and the truths of Keynesian economics. Doubts about the economic future appear to have led many toward more vocational programs. In addition, where men are concerned, William G. Bowen, Sarah E. Turner, and Marcia L. Witte have shown a correlation between the number of degrees granted ${ }^{2}$ in the early to mid1970s and the probability for a certain cohort of male students that entering graduate school would allow them to avoid the draft. Though they focus on the $\mathrm{BA}$ and $\mathrm{PhD}$, their findings pertain to the MA as well. They note that "when the draft law was changed to eliminate graduate school deferments," enrollment in graduate school promptly dropped:

The Selective Service Act of 1967 became effective 30 June 1967, and Executive Order No. 11360 contained provisions that meant that "after a one-year moratorium to end at the close of the 1967-1968 academic year, no more 2-S deferments would be granted to graduate students except those specifically written into the law." ... Under these dramatically changed conditions it is hardly surprising that the $\mathrm{Ph}$.D.-proclivity for men dropped from 6.4 percent for the B.A.-cohort of 1966 all the way to 3.7 percent for the B.A.-cohort of 1968 .

Figures 1 and 2 corroborate this understanding of the trend, since the lines for men's master's degrees promptly begin to decline in the early 1970s. L. E. Lewis commented on this shift in the ADE Bulletin in 1973: "the 
draft," he remarked, "is no longer a threat to most young men, and next year at this time the draft may be gone altogether" (34). Lewis understood that the draft's demise meant fewer male graduate students, especially at a time of economic depression. Still, the draft explanation accounts only for the period of the late 1960s and early 1970s; to explain more fully the decline in share, we must consider not only long-term economic trends but also the proliferation of degree programs and women's growing access to all areas of study.

The picture appears somewhat different when it is based on absolute numbers or on the various ways of calculating percentages of all degrees. Figures 4 and 5 show that as a percentage of the total number of master's degrees granted in English and foreign languages, men's degrees have dropped less sharply than women's over time. But figures 6 and 7 illustrate that women today earn a greater proportion of master's degrees in English and foreign languages than they did in 1966. Despite the sharp decline in the percentage of women who pursue the master's degree in these fields (figs. 4 and 5), the gap in the proportion of men and women earning such degrees has actually widened over the years (figs. 6 and 7). The correspondence between the "Total" and "Women" lines in figures 1 and 2 presents a good argument that the spike in the absolute number of master's degrees conferred in English and foreign languages in the early 1970s is attributable primarily to women's degrees, even though men began to turn away from these degrees only after 1970-71, perhaps in part because graduate study no longer secured draft deferral. Comparison of these figures illustrates the complexity of interpreting the place of the master's degree in the modern languages in the context of social upheaval, burgeoning new fields and their associated degree programs, and women's rapid entry into higher education generally and into fields formerly closed to them.

For both men and women, the economic slump of this period probably provided an incentive to pursue study in an area more immediately lucrative and more obviously vocational than the modern languages. In It Seemed Like Nothing Happened: America in the 1970s, Peter N. Carroll remarks that "in 1971, for the first time since 1893 (the year the historian Frederick Jackson Turner proclaimed the closing of the American frontier), the United States experienced a deficit of international trade" (127). Though President Nixon took belated action to cool inflation, during the first months of 1973 food prices rose at a rate of $9.2 \%$, a figure that would rise to $14.5 \%$ over the year. "A 1967 dollar in consumer prices," Carroll observes, "was worth sixty-eight cents in 1974" (132). The unprecedented aspect of the 1970s economic downturn, though, was that inflation raged at the same time that the economy was in recession. The result of this 
FIGURE 4

Master's Degrees in English Awarded to Women and to Men per Hundred of All Master's Degrees Awarded to Women and to MEN, 1966-98, 2000-01

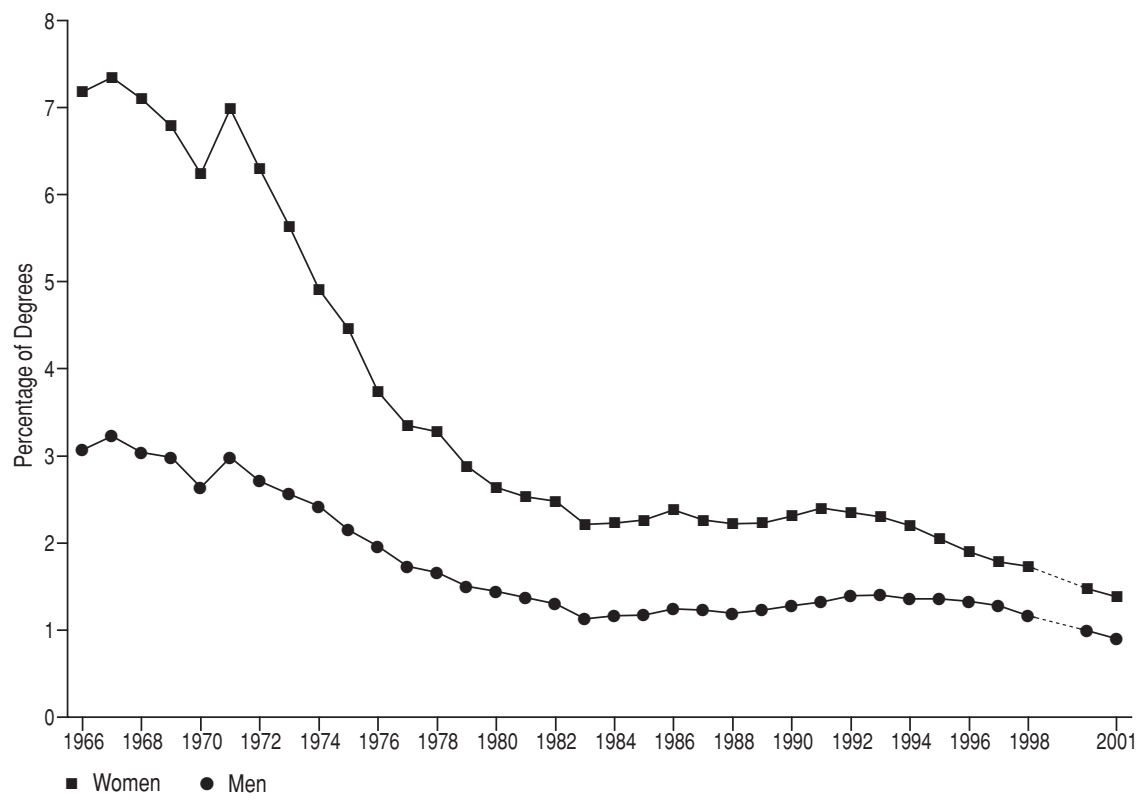

FIGURE 5

Master's Degrees in Foreign Languages Awarded to Women and to Men per Hundred of All Master's Degrees Awarded to WOMEn AND TO MEN, 1966-98, 2000-01

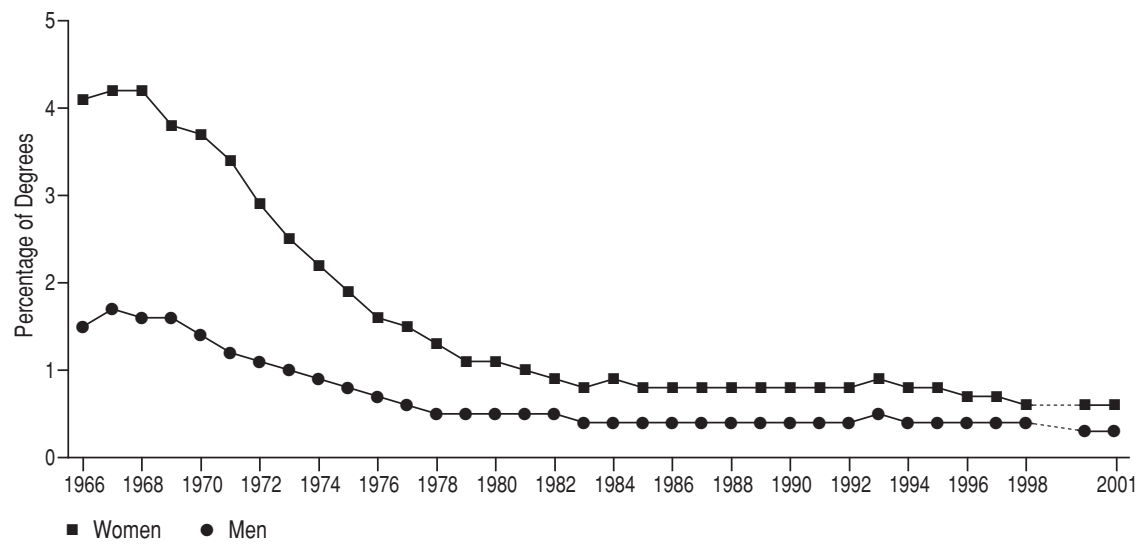


FIGURE 6

Master's Degrees in English Awarded to Women and to Men per Hundred of All Master's Degrees Awarded in English, 1966-98, 2000-01

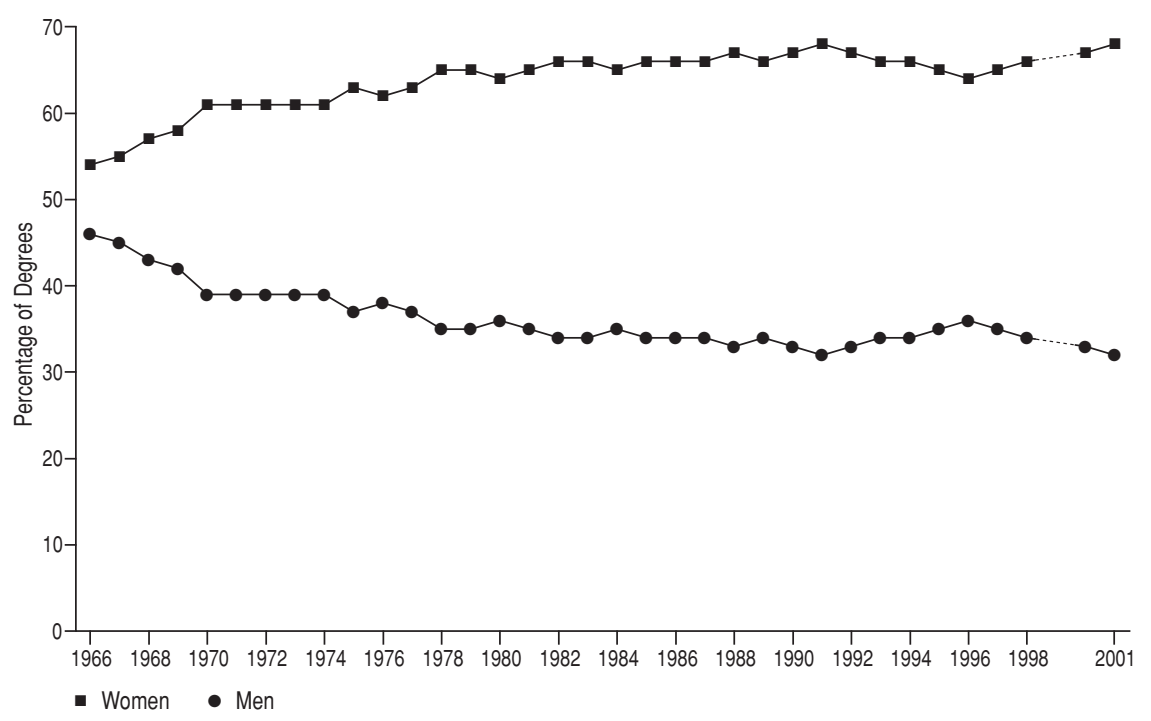

FIGURE 7

Master's Degrees in Foreign Languages Awarded to Women and to Men per Hundred of All Master's Degrees Awarded in Foreign Languages, 1966-98, 2000-01

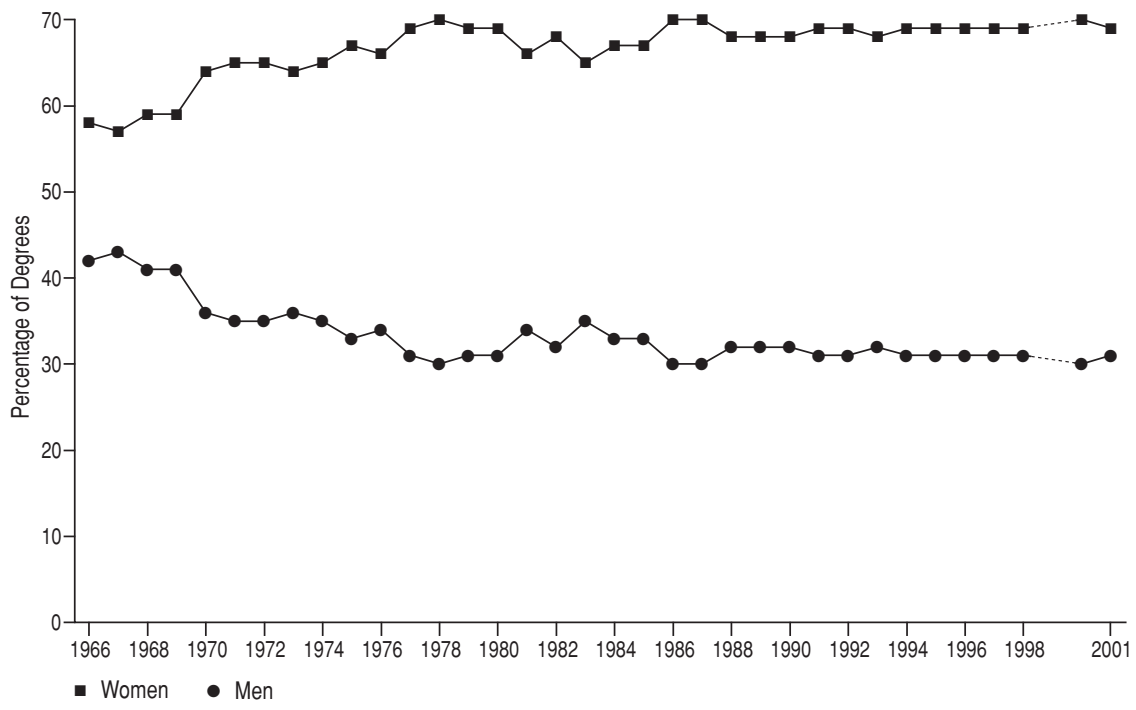


stagflation was that rates of unemployment reached sectors that had previously been unaffected by such downturns:

Unemployment among college graduates reached unprecedented levels, and the teaching professions entered an era of decline. Not only were there fewer jobs for teachers, but academic salaries also slipped 2.5 percent in real dollars between 1970 and 1973. "Teachers and social science majors can get loans," commented a banker about the doubling of defaults in the 1973-74 academic year, "but they can't get jobs." Such problems had an immediate impact on academic life, producing a drop in college enrollment, encouraging students to switch majors to marketable subjects such as business administration.

Such historical accounts of the period substantiate Lewis's anecdotal 1973 observation that "this year, for the first time in my young remembrance, my colleagues are thinking of bread and butter rather than plums" (34). Not only, then, were students disillusioned with nonvocational programs, Lewis's colleagues were worried as well that studying poetry about the icebox's purloined plums might not keep the icebox stocked with staples. Unemployment, inflation (especially in higher education), and the decline of the teaching professions are again prominent themes in 2004.

Other factors combined with the economic downturn to produce a decline in women's master's degrees in the modern languages, and here too we must look beyond the fields themselves to explain the drop. In fact, the statistical story behind the master's degree in the modern languages is to be found not at all in the number of English or foreign language degrees but (as Carroll intimates) in the number of other degrees conferred, and it is in these numbers that we begin to see why women's graduation rates in the modern languages drop in the early 1970s. Figure 8 shows the arc of degree conferrals in all master's fields from 1966 to 2001. Rising from 140,772 to 466,645 , the total has more than tripled over the course of the last three and a half decades. The rise in the number of master's degrees conferred illustrates, surely, the growing mass appeal and availability of higher education in the United States, but it also illustrates how women's entrance into higher education in general and more specifically into fields formerly dominated by men has shaped the distribution of degrees granted among the various disciplines. Whereas the number of master's degrees granted to men has risen by $105 \%$ since 1966, the number of degrees granted to women has risen by more than $450 \%$, giving women's degree decisions a much stronger influence on the shape of general trends than men's. This pull is evident in figure 8, which also breaks down by gender the number of master's degrees granted in all fields. The relatively steep upward slope of the line for all degrees reflects that of the women's line; the men's line ap- 
FIGURE 8

Master's Degrees Awarded to Women and to Men in All Fields, 1966-98, 2000-01

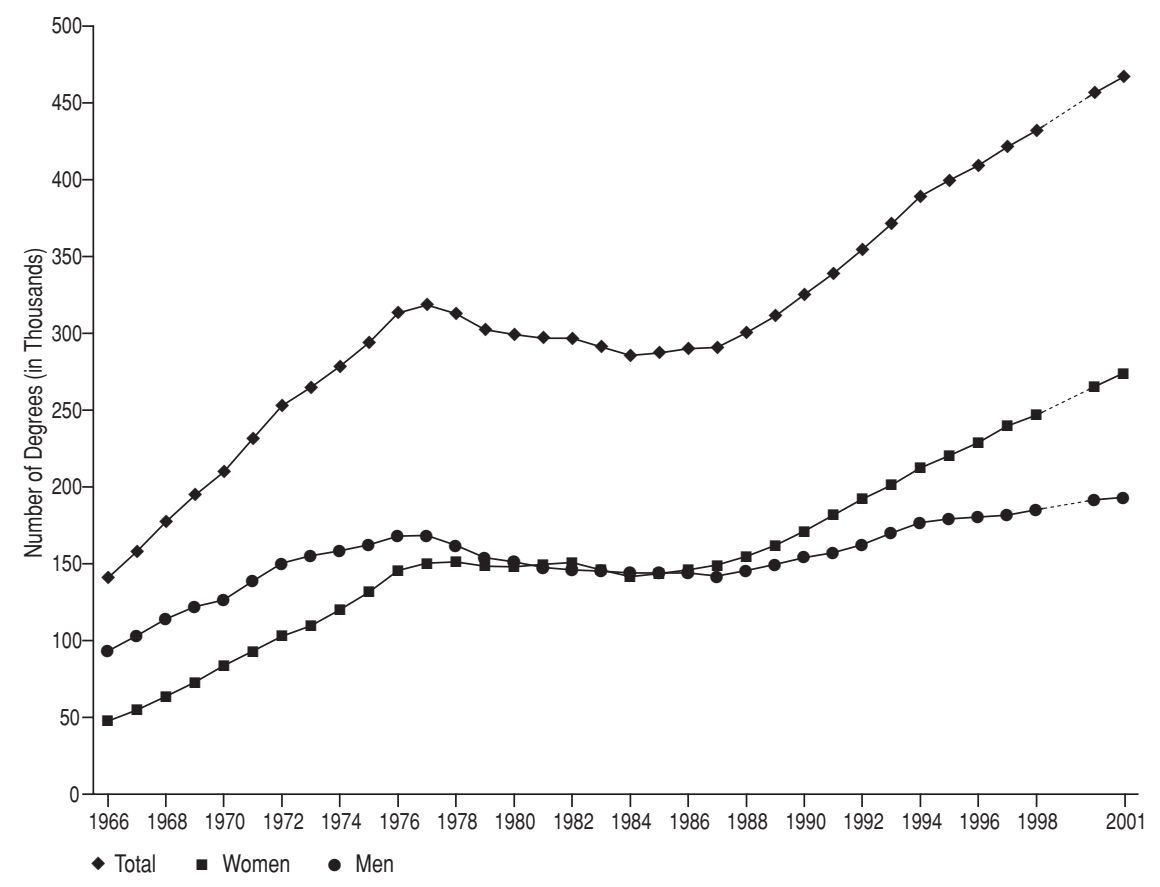

pears nearly flat by comparison, even though the percentage represented doubles over the course of thirty-five years. In figures 1 and 2, which focus on master's degrees in English and foreign languages, the shape of the line for all degrees also follows the line for women more closely than the one for men. Women's degree decisions, then, have shaped many general trends of the past three and a half decades more powerfully than have men's.

Women's greater likelihood of studying outside traditionally female areas was bolstered by legal and social changes regarding women. Bruce J. Schulman notes that "nearly every major news outlet ran stories on women's lib in the first months of 1970" (163), and in 1972 the Education Act barred discrimination against women in any program that received federal funding. As women's rights gained public acceptance, women began to assume a more prominent role in government. Schulman remarks that this new level of participation in government

precipitated substantial policy changes during the 1970s. New laws prohibited sex discrimination in the armed services and educational 
institutions, and employment discrimination against pregnant women. The Women's Educational Equity Act Program, enacted in 1974, provided federal funds to public schools that actively countered sex role stereotypes and promoted equality of women's educational opportunities.

Because consciousness of sex discrimination reached a critical mass during the early 1970s, Karen Mason, John Czajka, and Sara Arber report, "the sex-role attitude changes observed ... for the 1970-73 period are, in many instances, as large as those observed between 1964 and 1970, even though the time period is half as long" (587). As women became more aware of the women's movement, they participated more fully in higher education and government; in the process they enhanced other women's ability to do the same, accelerating the rate at which women's choices changed.

The effects of this accelerated change are apparent in figure 9, which shows English and foreign languages as well as comparison disciplines. Of these comparison disciplines, most remain relatively flat over the course of the thirty-five years, despite the dramatic increase in the total number of master's degrees conferred in all disciplines. In history (the line for which is nearly identical to that for foreign languages) and sociology, some decline is also evident in the early 1970 s. However, a major such as psychol-

\section{FIGURE 9}

Master's Degrees in Six Related Disciplines, 1966-98, 2000-01

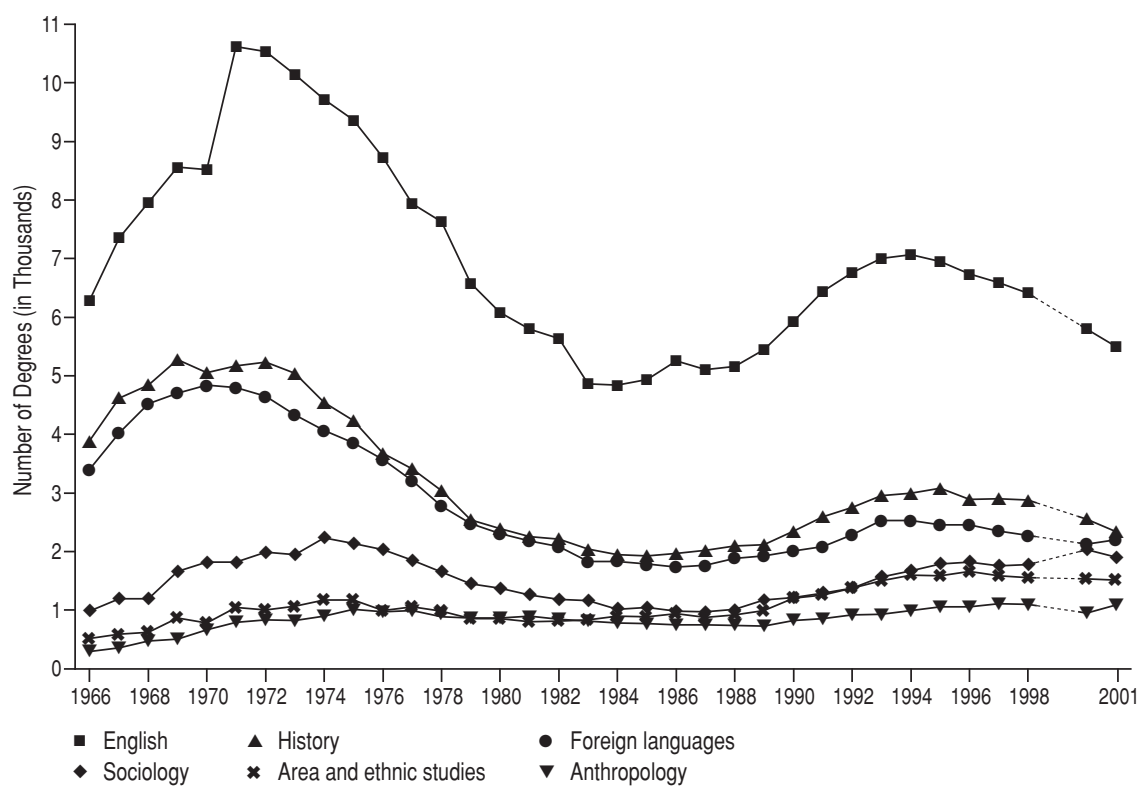


ogy, which has consistently attracted high numbers of women over time, shows a significant if not steep incline (fig. 10). In fact, figure 10 shows that women's enrollments have been the driving force behind psychology's surge in master's graduates: the trend in men's master's degrees appears flat by comparison with women's. Similarly, the master's in nonscientific education, which attracted nearly equal numbers of men and women in 1966, has since then seen its graduation rates driven sharply upward by women (fig. 11). Even in a field in which women still lag behind men, such as business and management, women have had a powerful effect on the arc of upward graduation rates. As figure 12 shows, the total number of master's degrees in business and management and the number of men's degrees in this field were nearly identical in 1966. By 1976, women were earning over 5,000 of these degrees per year; in the next decade the number quadrupled to 20,000, and then more than doubled again by 2001. Whereas women have increasingly shown a tendency to enter fields not traditionally associated with women, the reverse is not true: as Jerry A. Jacobs remarks, men have not responded to the breakdown of limitations on women by

\section{FIGURE 10}

Master's Degrees in Psychology, 1966-98, 2000-01

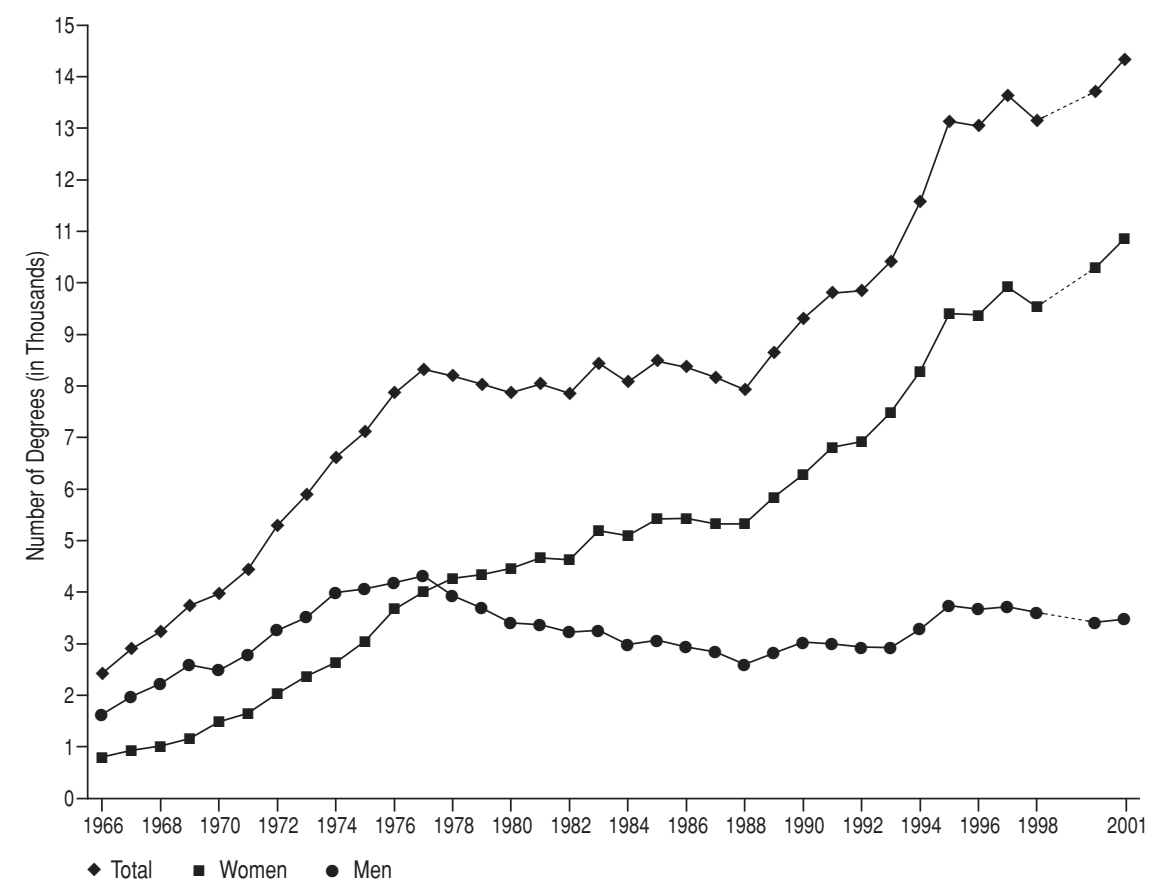




\section{FIGURE 11}

Master's Degrees in Nonscientific Education, 1966-98, 2000-01

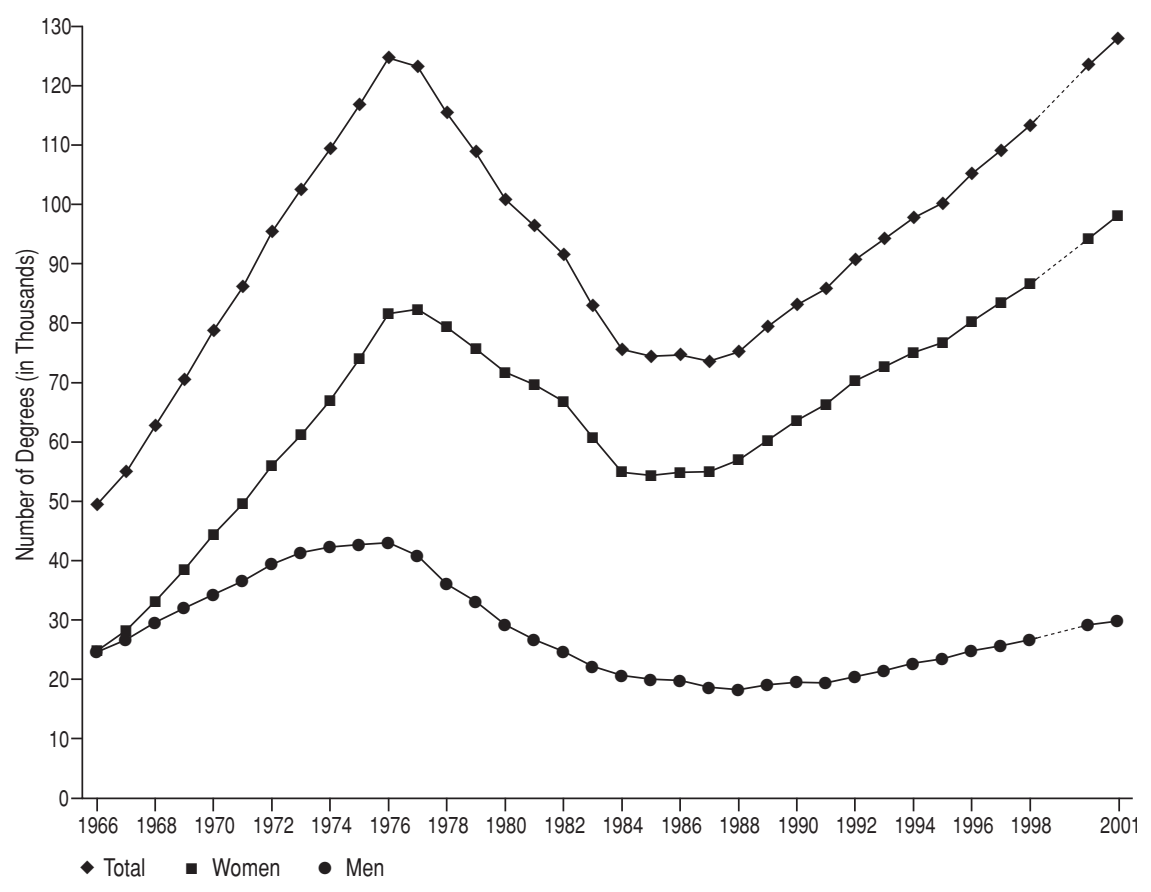

entering in greater numbers the fields to which women were formerly limited (96). As a result, in many humanities disciplines men's percentage share of all master's degrees granted has dropped dramatically over the years even as their total number of master's degrees granted has climbed.

As figure 3 shows, the modern languages' percentage share of the total number of master's degrees drops markedly in the early 1970s. This period appears to be the moment of an impressive-and anomalous-historic high in figures 1 and 2; it does not appear so impressive in figure 3. In foreign languages, this period is roughly on a par with the late 1960s in English and already shows a decline. Since the number of master's degrees conferred in all fields had risen dramatically by 1971, the actual share of all degrees for English rose only modestly, despite the jump in absolute numbers of English master's degrees. After this year, English's percentage share does drop dramatically, even though the number of degrees granted in English remains more or less constant over the entire period. The downward curve for foreign languages shows a similar trend. Comparison of these figures suggests, then, that the modern languages were able to attract a con- 
Master's Degrees in Business and Management, 1966-98, 2000-01

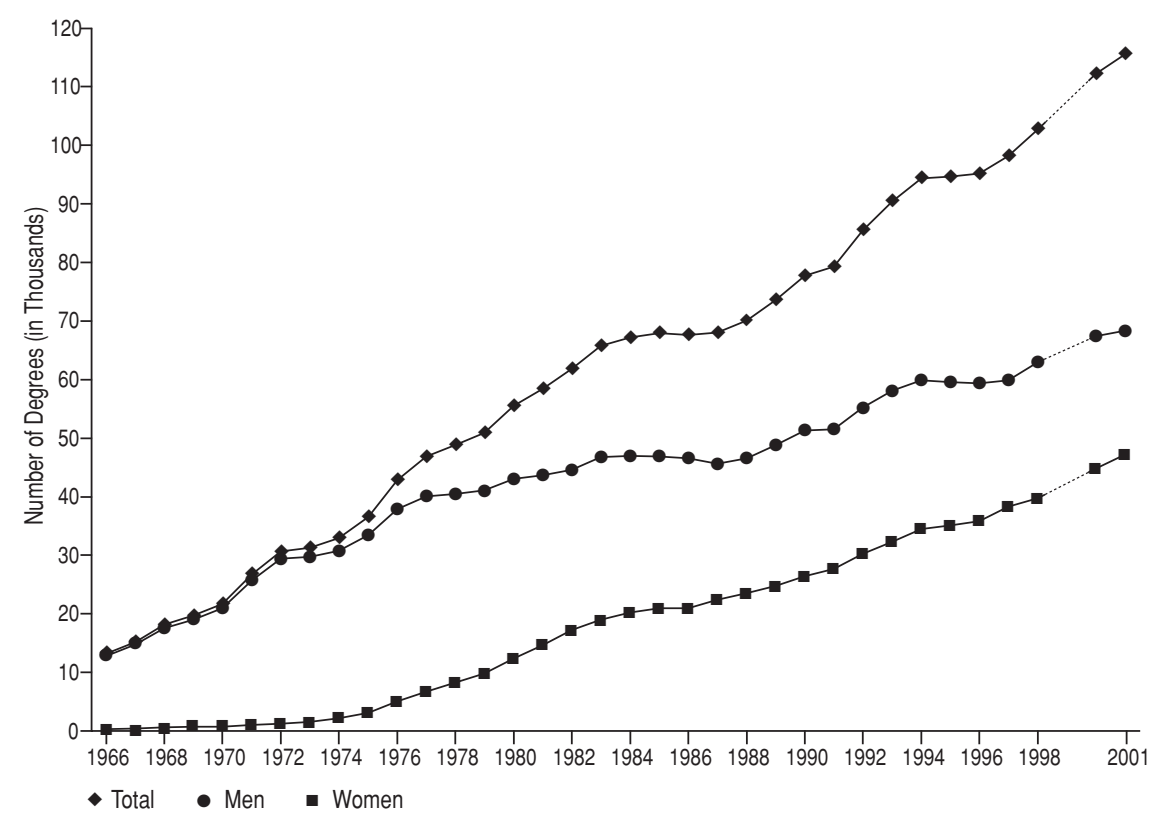

sistent percentage share of the master's degree market through the early 1970s but that since then this share has consistently dropped and shows no sign of reversing its downward trend, though the field regained a bit of ground in the late 1980s and early 1990s. ${ }^{3}$ English's percentage share grew steadily from 1950 to the early 1970s and is now approximately back at its 1950 level. In this regard, English is typical of the humanities disciplines. In the words of Bowen, Turner, and Witte, "During the two decades between 1954 and 1974, the total number of bachelor's degrees awarded rose steadily and rapidly. ... A 'flight from the arts and sciences' then commenced" (69).

To counter this decades-long flight, a renewed conversation about the purpose and methods of master's degree programs has recently arisen in the humanities and science disciplines. Mary M. Gaylord frankly remarks, "The one area of agreement has been the concept of the master's as an intermediate degree on the road that leads to the $\mathrm{PhD}$," and she admits that "applicants incautious enough to let us know that they want to use the MA to test the academic waters or decide where their true interests lie are certain to be turned down" (1267). Gaylord's view is borne out by statistics on master's degree conferrals. Figures 13 and 14 compare bachelor's, master's, and doctoral degrees as percentages of all degrees granted in English, 
foreign languages, and all fields. These figures show that, relative to all fields, a greater percentage of degrees in the modern languages is at the bachelor's level, a smaller percentage is at the master's level, and a similar percentage is at the doctoral level. For instance, $13.3 \%$ of foreign language and $9.6 \%$ of English degrees were master's degrees in 2001, but $26.4 \%$ of degrees in all fields were master's degrees. The difference suggests that, within the modern languages, master's degrees are underrepresented, bachelor's degrees are overrepresented, and doctoral degrees are equably represented. Master's degrees in the modern languages are also underrepresented among master's degrees in all fields (figs. 15 and 16). Looking at bachelor's, master's, and doctoral degrees in English and foreign languages as a percentage of those degrees in all fields shows that the modern languages claim the lowest percentage of all master's degrees and that the percentage of master's degrees has fallen more sharply since 1966 than the percentages of

FIGURE 13

English Bachelor's, Master's, and Doctoral Degrees per Hundred of All Degrees in English; the Same Comparison in All FieldS, 1966-98, 2000-01

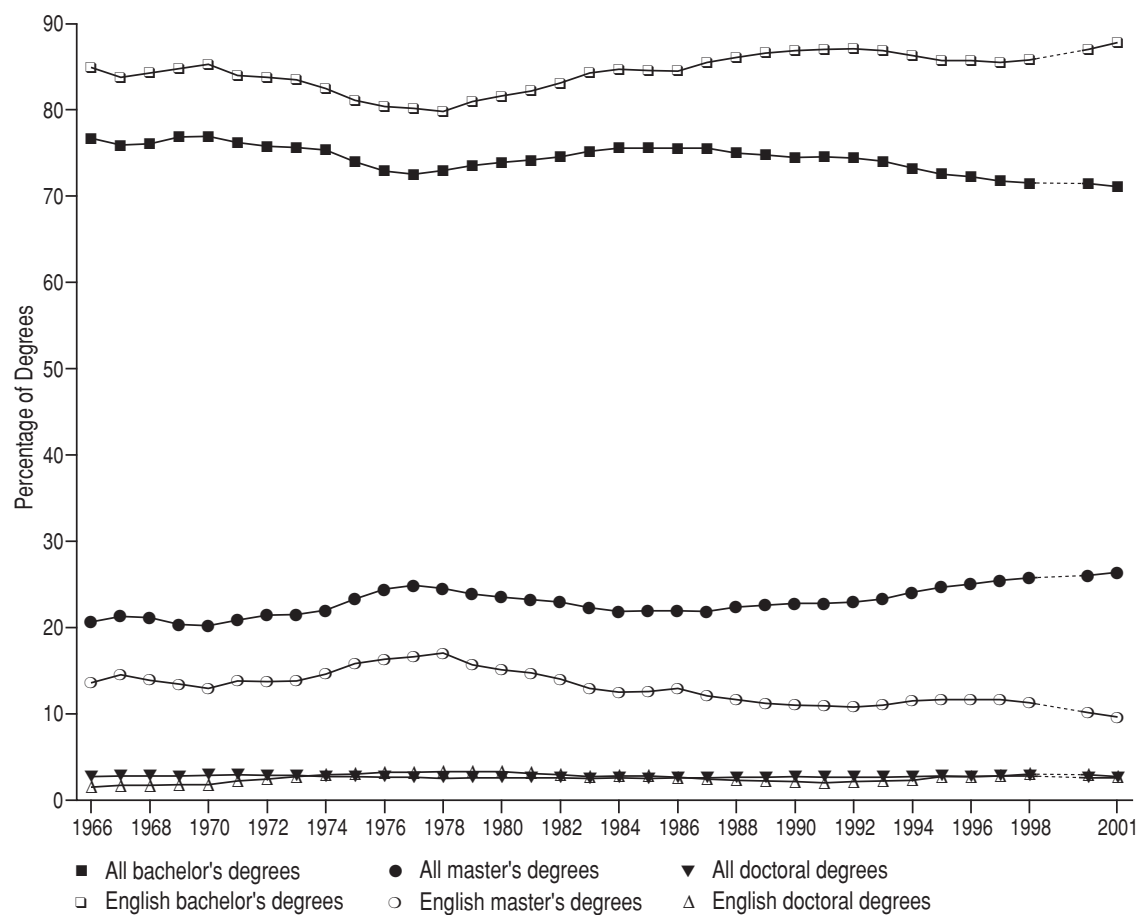


doctoral and bachelor's degrees. In 2001, foreign languages claimed 1.47\% of all PhDs but only $0.47 \%$ of all master's degrees; English claimed 3.42\% of all $\mathrm{PhDs}$ but only $1.18 \%$ of all master's degrees. If we judge from these figures, the "flight from the arts and sciences" has disproportionately affected the master's degree in the modern languages. However, the figures also suggest that there is room for growth in the conferral of the degree.

Intuiting this room for growth, Gaylord expresses some optimism for the future of the master's degree, noting that the job market cannot accommodate the many PhDs that flood it every year but that "the same market has much more room for master's-degree holders" (1268). From the vantage of her own highly visible institution, Harvard University, which does not offer a terminal master's in English, she offers a vision to counter the flight:

A restrung and refurbished MA will not change the world overnight, but visible commitment from highly visible institutions to rigorously defined

FIGURE 14

Foreign language Bachelor's, Master's, and Doctoral Degrees per Hundred of All Degrees in Foreign languages; the Same Comparison in All Fields, 1966-98, 2000-01

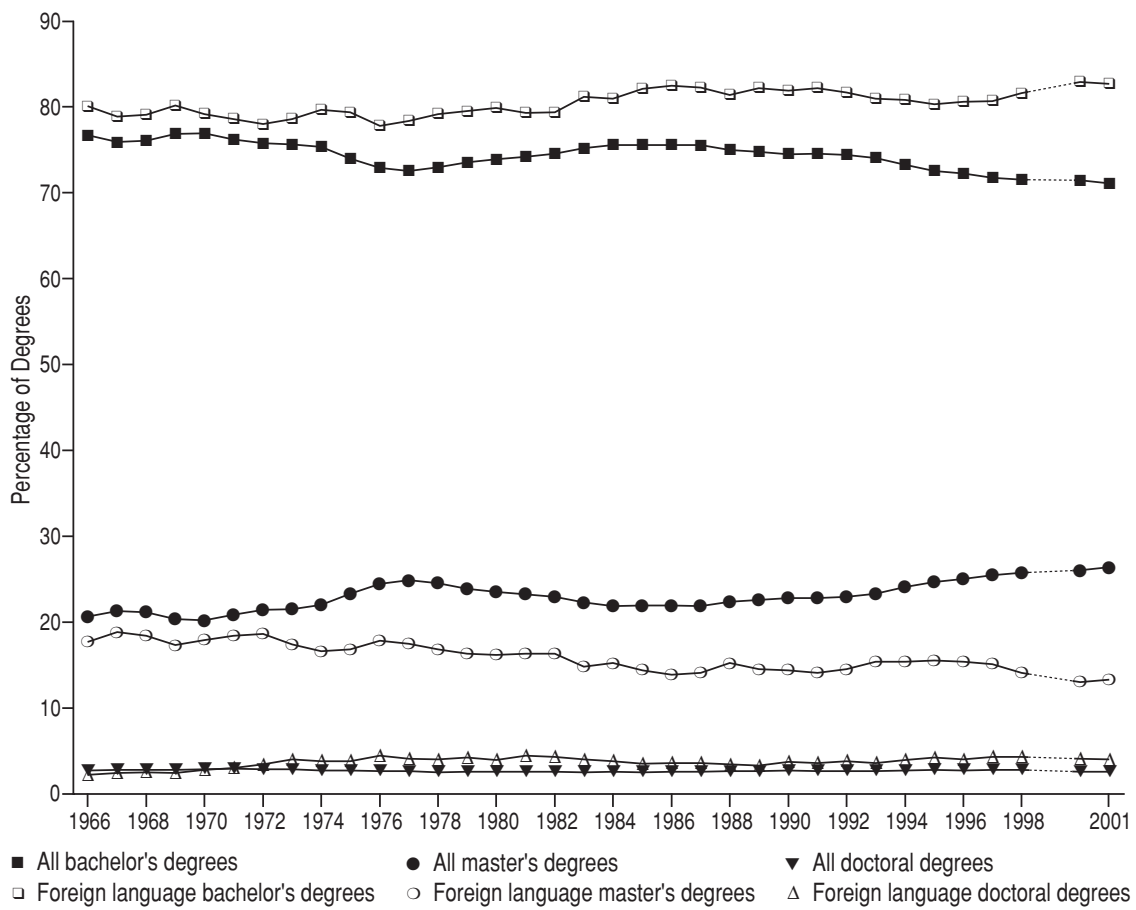




\section{FIGURE 15}

Bachelor's, Master's, and Doctoral Degrees in English per Hundred of Those Degrees in All Fields, 1966-98, 2000-01

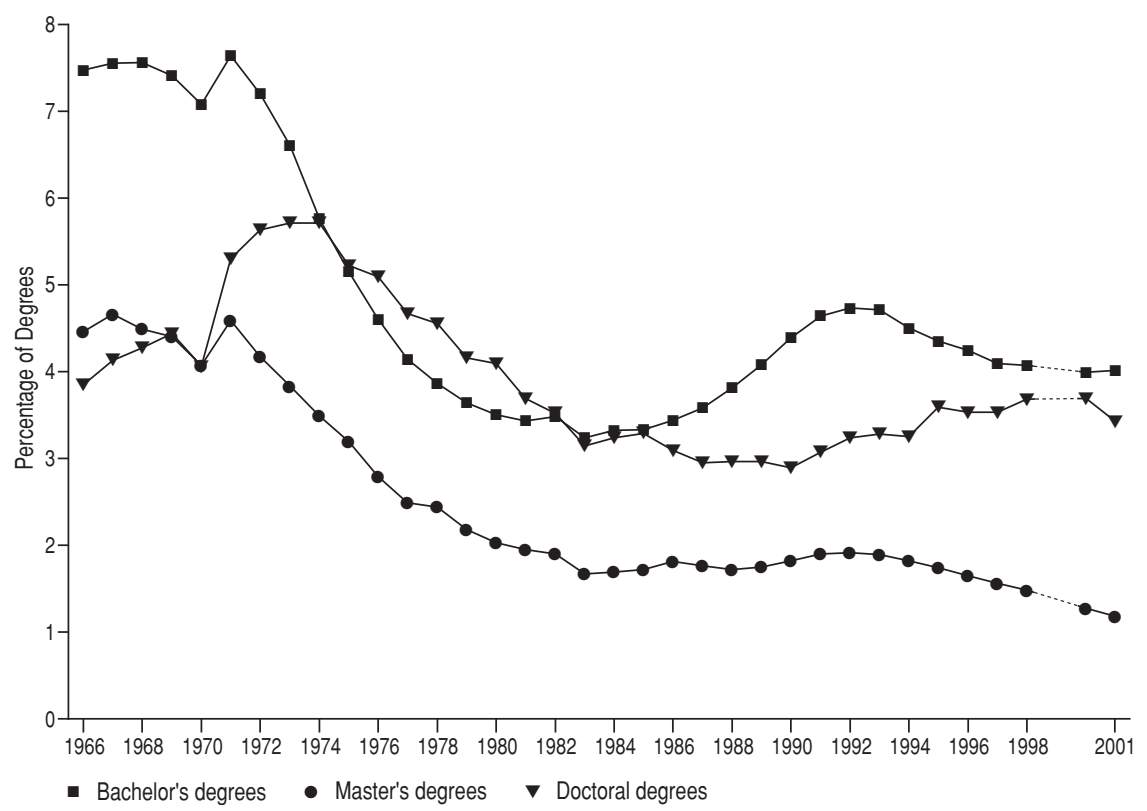

FIGURE 16

Bachelor's, Master's, and Doctoral Degrees in Foreign Languages per Hundred of Those Degrees in All Fields, 1966-98, 2000-01

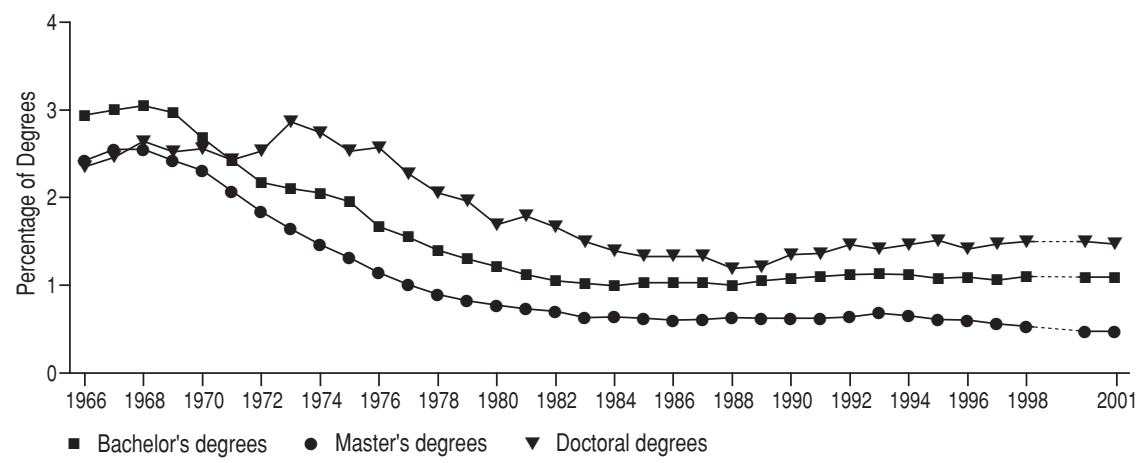


basic skills and knowledge, to user-friendly pedagogy, to the improvement of public secondary education, can only strengthen the image of what the humanities are and what they are good for.

Denise K. Magner reports that administrators on several campuses echo this sentiment, seeing in the master's degree not only a possible panacea for financially strapped universities but also a means of representing to a wider public the value inherent in humanities study. At the 2003 ADE Summer Seminar in Minneapolis, participants at a well-attended discussion of the master's degree enthusiastically discussed its possibilities, rationale, and curricula at a variety of institutions, and they asked the ADE to create a discussion list devoted to the master's degree. ${ }^{4}$ In the Chronicle of Higher Education, Alison Schneider reports that many professors now hold the view that "master of arts programs are 'testing grounds,' 'prototypes'-harbingers of a bright new era in graduate education.... They're the cure for what has been ailing higher education: too many Ph.D.'s, too few jobs. . . . Academe's ugly duckling has become its newest little darling." Schneider suggests that the "career-minded direction" of master's programs "opens up professional opportunities," and she cites proponents of such programs who are touting their "practical intellectualism" and "pragmatic" quality. Many of these new master's degree initiatives focus on the humanities, though, or some other interdisciplinary configuration, not a specific discipline. They do little to bolster the number of students graduating with a master's in a modern language, and they also make it difficult to determine how much master's-level work is being done under the direction of graduate faculty members in the modern languages.

Schneider gushes, "The hip, interdisciplinary bent of the new M.A. programs breaks away from stodgy departmental divisions." But not everyone shares that rosy view of the new master's initiatives in the humanities, and concerns about the effect that interdisciplinary programs have on specific departments have been around for decades. In 1973, for instance, the MLA published Prospects for the 70's: English Departments and Multidisciplinary Study, edited by Harry Finestone and Michael F. Shugrue, precisely at the moment that English's percentage share was about to slip, just as some of the volume's contributors presciently feared. If the contributors were not very concerned about the implications for English of the burgeoning population of women students in other fields, they did understand that the economic crisis and social protest movements had eroded the credibility and viability of the humanities in the public's eye: humanities majors were disruptive, idealistic plums in a country that was suddenly short of bread and butter. Tellingly, of the eighteen contributors, only one 
was a woman. Men earned twice as many $\mathrm{PhDs}$ as women every year until 1973, and women did not surpass men in earning English PhDs until 1981, the same time that they surpassed men in earning master's degrees (fig. 17). Though the contributors to Prospects seem in retrospect to have ignored the importance of developments in women's degree decisions, they generally agreed that interdisciplinary programs were good for English study and good for students. The editors remarked that such programs might respond to "changes in student interests and needs" by countering "the heavily vocational or professional training given by most English departments" (vi). It is difficult to know what to make of such a prognosis when it is juxtaposed with Carroll's view that students were at this moment looking, quite precisely, for something more vocational than a degree in the humanities.

Voicing a different kind of student-centered criticism today, Cary Nelson has accused interdisciplinary master's degree programs of using master's students in order to float their $\mathrm{PhD}$ programs without providing the students with any clear career direction in return. "Unless you have a graduate program that is pointed toward a plausible career," he argues, "you don't have any excuse for running a program that puts people into serious debt" (qtd. in Schneider). Proponents counter that the new programs may

FIGURE 17

All Master's Degrees Granted, by Gender, per Hundred, 1966-98, 2000-01

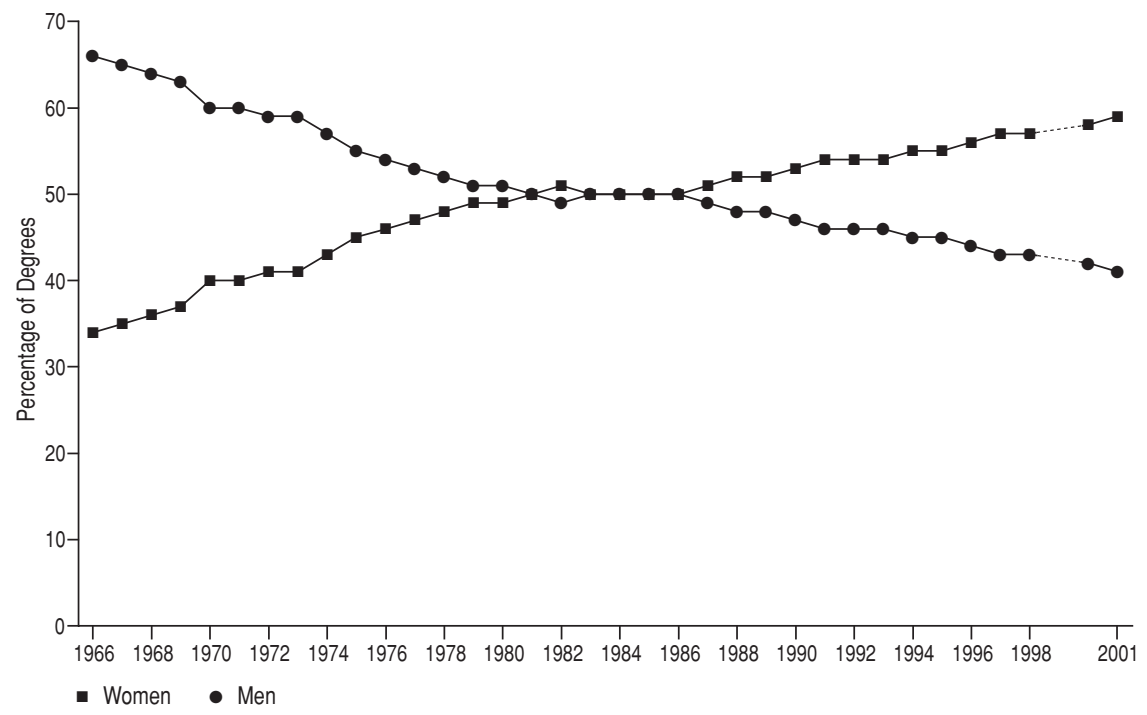


make cutthroat $\mathrm{PhD}$ programs more humane, directing some students from the start toward a terminal master's rather than simply refusing to allow half of them to proceed to the $\mathrm{PhD}$. Throughout its history, the master's degree has teetered on the divide between vocational and $\mathrm{PhD}$ preparation, and this divide seems still to trouble the new interdisciplinary programs. Faculty members primarily interested in doctoral education's depth of research find the interdisciplinary master's degree to be overly vocational; other critics of the degree, such as Nelson, find it to be insufficiently vocational.

The master's degree in traditional disciplines, too, has oscillated between these poles for some time. Reporting on an MLA survey from the mid-1980s, Monica S. Devens writes that a public university in the Midwest was instituting new programs to enhance its attractiveness to potential students. The master's degree in French targeted "the population that has been working for a while and feels a need for graduate humanities work unrelated to actual career aspirations," but the program in Asian languages, according to the chair of that department,

is not designed to compete with the major $\mathrm{PhD}$ programs in the field; they are producing enough $\mathrm{PhDs}$ as it is. ... It will have a practical rather than a scholarly orientation.... We envision future employment in government or business for these students.

Both new master's degree programs were in foreign language departments at the same institution, but the departments arrived at contrary rationales for them.

Marcia A. Dalbey casts this divide between vocational and academic purposes as flexibility when she observes:

Some of these tracks [in our MA program] offer clear professional credentials; others serve that purpose for some students. Part of the student demand may well reflect "degree inflation." For many professions, including public school teaching, the MA is now a minimum requirement for retaining, if not obtaining, a job.

She notes, too, that many of Eastern Michigan University's master's students were inadequately prepared to go directly into a $\mathrm{PhD}$ program, often because of factors related to their working-class backgrounds. Bernard Duyfhuizen echoes Dalbey's comments, remarking:

If it wasn't for teachers needing graduate courses to maintain their licenses or to attain initial certification, for geographically bound students wanting something beyond the $\mathrm{BA}$, and for the occasional pre- $\mathrm{PhD}$ 
student trying to bolster a shaky transcript and to prepare for the GREs, the Eau Claire program would have gone under.

For regional institutions like Eastern Michigan University, the master's degree appears to serve a more traditional function than the trendy programs that Schneider describes at universities with high national visibility.

A new emphasis on the master's degree is not limited to humanities disciplines. In the sciences many also see the master's degree as a response to the overproduction of $\mathrm{PhDs}$, a response that maintains, or increases, students' interest in the discipline. Since 1997, the Sloan Foundation has underwritten the start-up of dozens of professional master's degree programs around the country, seeing them as a useful alternative to the $\mathrm{PhD}$. Since the foundation understands the master's as a professional degree, it fosters programs fitting into three profiles:

- those that deepen a student's knowledge beyond what can be learned in a fouryear course of study, but stay within a disciplinary domain;

- those that fuse scientific fields at a level of depth and complexity hard for undergraduates to achieve; in many cases, the fusion may be with computer or information sciences; and

- those that integrate study in the natural sciences and mathematics with knowledge and training in management, law, or other professional domains.

(Program Rationale)

As the last profile indicates, the new master's degrees in science often include course work in clearly vocational arenas, offering a compromise between fully vocational programs and fully academic programs. The development of innovative master's programs in the science disciplines, as well as in the humanities, suggests that the master's, once considered a "lesser" degree (Woolston), is gaining a secure place in its own right in a whole range of disciplines and at a variety of institutions.

As in the sciences, testimonies such as Duyfhuizen's and Dalbey's, together with reports such as Schneider's and Devens's, depict master's degrees in the modern languages that are neither clearly directed toward bread-and-butter careers nor fully devoted to plum humanistic study; degrees that are a newfound cash cow in one location but struggling to hold their own against administrative attempts to eliminate them for fiscal reasons in another; and degrees that might increase the number of graduates in the modern languages despite a tenure-track hiring market that cannot absorb the number of PhDs produced..$^{5}$ Among the emerging areas of interest at the master's level, creative writing, teacher education, and Spanish merit particular attention in the coming years. 
Figure 18 gives some indication of the growth in creative writing. ${ }^{6}$ Like the boutique interdisciplinary master's degrees, creative writing is liable to the accusation of student exploitation in a depressed hiring market. This accusation raises fundamental questions about the purpose of the master's degree: Should the outcome of a creative writing master's degree be primarily excellent creative writing or a job? An acquaintance who teaches creative writing recently told me that one of her students had dreamily avowed his desire to do what she does-that is, teach creative writing. "You can't," she thought, seeing the job market as a zero-sum game, "I'm doing it."

Such a scenario is not likely for the master's degree in teacher education, since students pursuing it teach at the less competitive elementary and secondary levels. Figures 19 and 20 show that conferrals of this degree have doubled in English and nearly tripled in foreign languages since 1987. Here again it is primarily women's degrees that have driven the upward trend. One NCES report, Teacher Preparation and Professional Development: 2000 , finds that about $45 \%$ of all public secondary school teachers hold a master's degree, with the percentage being higher among teachers with more experience (Parsad et al.). Not all these degrees would be in education, but this finding does corroborate Dalbey's and Duyfhuizen's view that

FIGURE 18

Master's Degrees in Creative Writing and English Language and Literature-LeTters, 1987-98, 2000-01

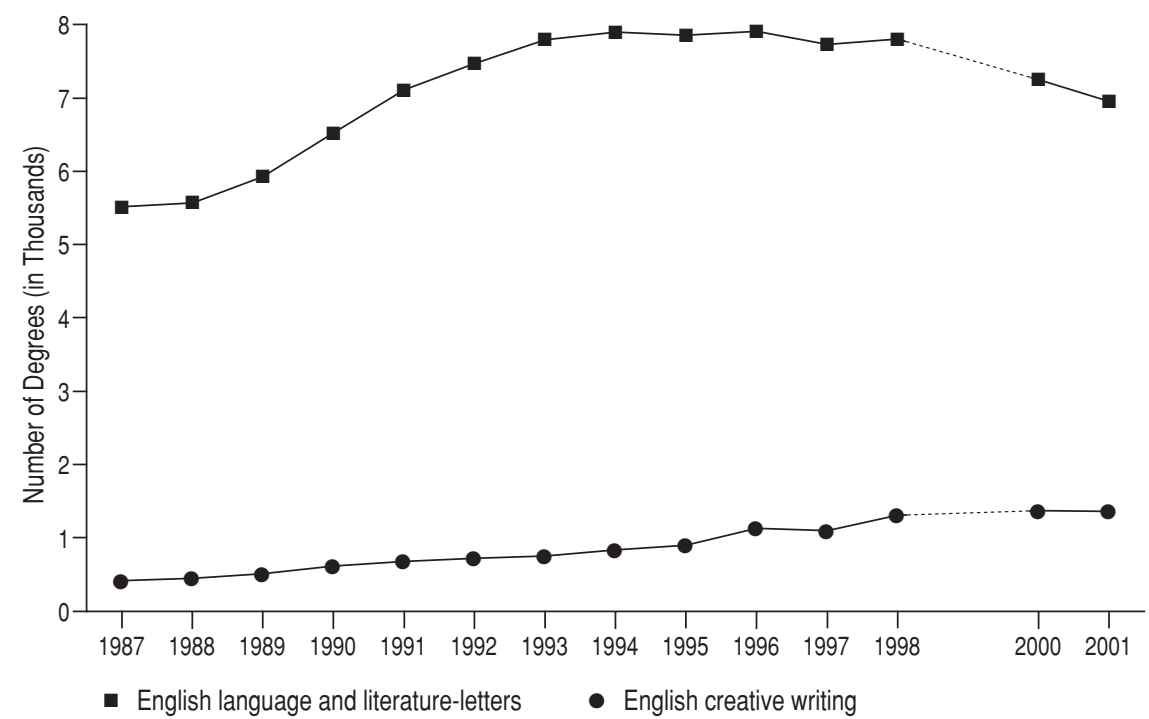


FIGURE 19

Master's Degrees in English Teacher Education, by Gender, 1987-98, 2000-01

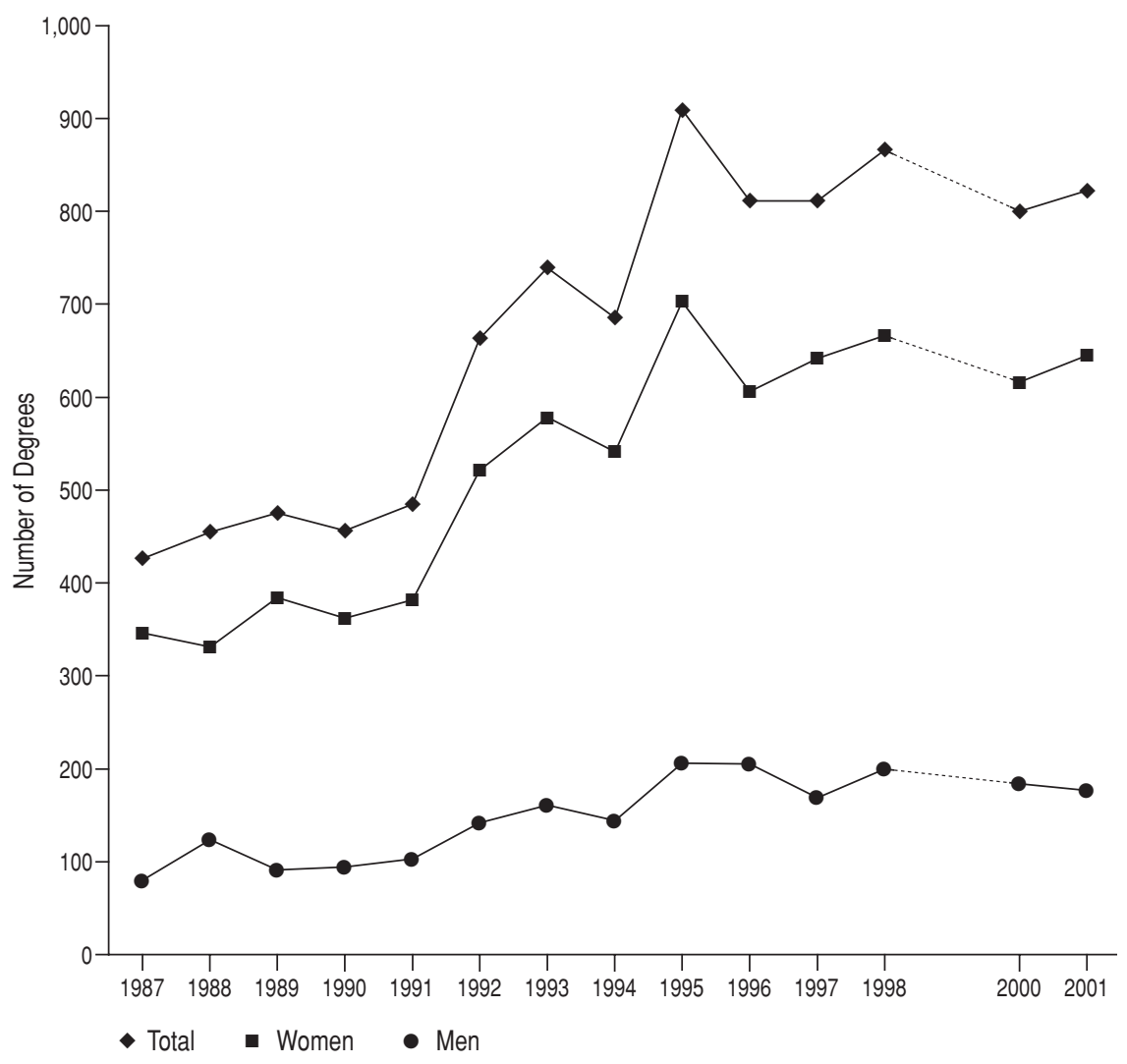

the master's degree is of special use to secondary teachers as they retain licensure and attain promotion. The education degree is a frankly vocational one, though, and unlikely to attract the same level of attention from research-oriented faculty members that literature, theory, and cultural studies do.

The problem of not attracting students does not afflict the field of Spanish, which, as figure 21 shows, is modestly gaining master's graduates while French and German graduation rates slowly erode or barely hold steady.

The master's degree in the modern languages clearly serves diverse and sometimes antithetical purposes, depending on institution, mission, and prestige, not to mention individual students' goals and previous preparation. A decreasing percentage of students, especially women, have 
FIGURE 20

Master's Degrees in Foreign Language Teacher Education, by GENDER, 1987-98, 2000-01

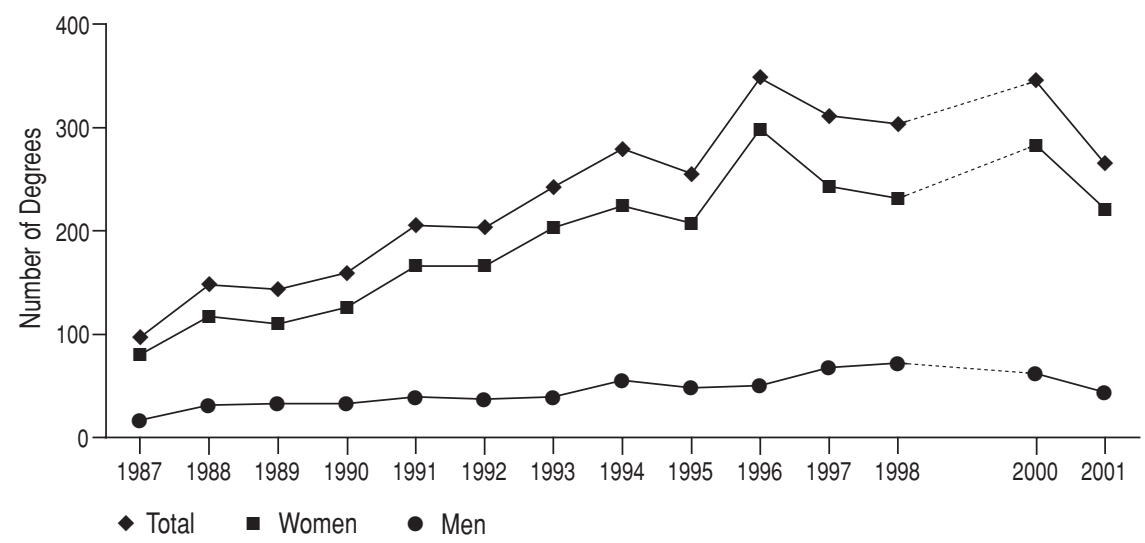

FIGURE 21

Master's Degrees in Spanish, French, and German per Hundred of All Master's Degrees in Foreign Languages, 1987-98, 2000-01

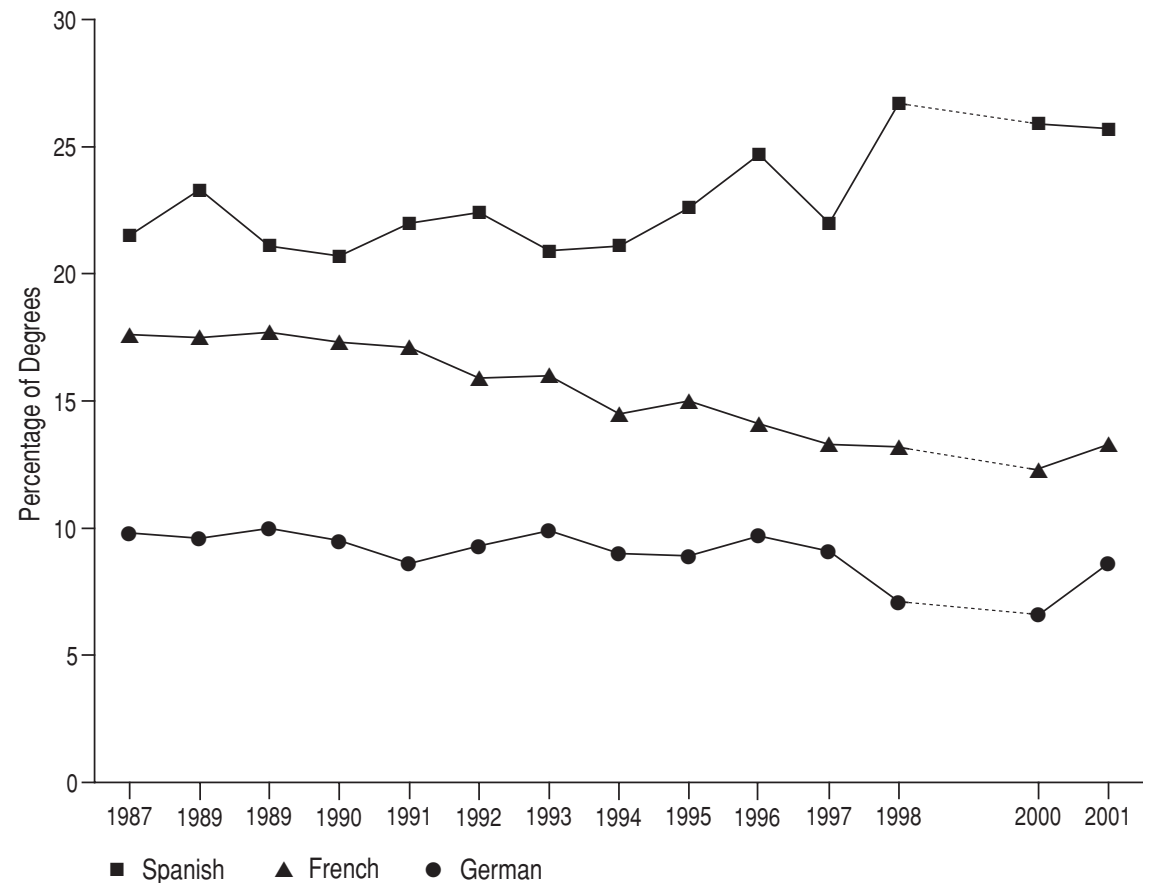


pursued master's degrees in the modern languages. Given the economic and social conditions that initiated this decline in the early 1970s, it appears that the degree's lack of obvious vocational direction and women's increasing parity in other fields have been major factors. New master's degree programs may do something to reverse the "flight from the arts and sciences," but it remains to be seen whether or not such programs, frequently interdisciplinary, will have a substantial impact on the modern languages' future share of master's degrees.

\section{NOTES}

${ }^{1}$ All figures derive from data available on WebCASPAR, a site maintained by the $\mathrm{Na}$ tional Science Foundation (NSF) at caspar.nsf.gov. Data from 1966-98 and 2000-01 derive from the Survey of Earned Degrees of the National Center for Education Statistics (NCES). The NCES also compiled the data on subsets of the English major in 1987-98 and 2000-01 for the Integrated Postsecondary Education Data System (IPEDS). Both data sets are manipulable by gender, among other variables. Only figures 18 through 21 derive from the later, more specialized IPEDS data. For this reason, totals in figure 18 do not match those in other figures with similar data.

${ }^{2}$ Bowen, Turner, and Witte consider only six fields in the arts and sciences: English, history, political science, economics, mathematics, and physics. For this reason, figure 8 , which shows the climb in the number of master's degrees in all fields, does not reflect the trends they discuss.

${ }^{3}$ Curiously enough, there appears to be some correlation between this ground regained and Jacobs's findings. Jacobs argues, "During the late 1960s, 1970s, and early 1980s, the segregation of men and women in fields of study dropped precipitously"; however, this development was followed by "a dramatic slowdown in the trend toward gender integration during the late 1980s" (81). Moreover, "the timing of change was remarkably similar at all levels of higher education. The movement toward gender integration slowed down at the same time for recipients of associate degrees as for recipients of Ph.D.s, master's and professional degrees, and bachelor's degrees," a mass trend that he attributes to the stabilization of "the social controls that channel women into female-dominated fields" (95). Still, it is apparent from figures 1 and 2 that the number of master's degrees in the modern languages conferred on men also rose slightly between the mid-1980s and mid-1990s.

${ }^{4}$ To be added to the ADE's discussion list devoted to the master's degree (MADEG-L), please e-mail ade@mla.org. Be sure to include your name, institutional affiliation, and e-mail address. The MLA has recently launched an online Guide to Doctoral Programs in English and Other Modern Languages. The Guide includes a full range of data on doctoral programs from admission to placement and will serve as an online means of gathering such data. After ensuring that this system of data gathering and analysis functions properly, the MLA will expand the Guide to include data on master's and, eventually, bachelor's programs.

${ }^{5}$ In 1968, in The Ph.D. in English and American Literature: A Report to the Profession and the Public, Don Cameron Allen floated the idea that granting more master's degrees might help alleviate the shortage of PhDs to teach at the university level (97). That the master's degree is today suggested as a remedy to a surplus of qualified PhDs serves as a 
useful reminder of how difficult it is to predict the future. It also underscores the longstanding uncertainty over what the master's is really good for.

${ }^{6}$ However, the NCES has collected these data only since 1987, many students who pursue creative writing course work may not earn an English degree, those who do may have no indication on their degree of having concentrated in creative writing, and the institution-reported IPEDS categories overlap. It is difficult, therefore, to know just how large a share of earned English degrees should be attributed to students whose primary interest is creative writing. Institutions' familiarity with IPEDS terminology and greater clarity at the departmental level about which students concentrate in creative writing should produce more accurate figures with time.

\section{WORKS CITED}

Allen, Don Cameron. The Ph.D. in English and American Literature: A Report to the Profession and the Public. New York: Holt, Rinehart, 1968.

Bowen, William G., Sarah E. Turner, and Marcia L. Witte. "The B.A.-Ph.D. Nexus.” Fournal of Higher Education 63 (1992): 65-86.

Carroll, Peter N. It Seemed Like Nothing Happened: America in the 1970s. New Brunswick: Rutgers UP, 1990.

Dalbey, Marcia A. "What Good Is the MA Degree?” ADE Bulletin 112 (1995): 17-20.

Devens, Monica S. "Graduate Education in Foreign Languages and Literatures: A View from Five Universities." ADFL Bulletin 17.3 (1986): 14-18.

Duyfhuizen, Bernard. "Betwixt and Between: The Master's Program and a Field of Dreams." ADE Bulletin 112 (1995): 21-24.

Finestone, Harry, and Michael F. Shugrue, eds. Prospects for the 70's: English Departments and Multidisciplinary Study. New York: MLA, 1973.

Gaylord, Mary M. "On the Outside Looking In: Some Thoughts about the MA Degree." PMLA 115 (2000): 1267-69.

Jacobs, Jerry A. "Gender and Academic Specialties: Trends among Recipients of College Degrees in the 1980s." Sociology of Education 68 (1995): 81-98.

Lewis, L. E. "The English Department and the Depression." ADE Bulletin 36 (1973): 34-40.

Magner, Denise K. "Master's Degrees Are the Hot Topic at a Meeting on Doctoral Education." Chronicle of Higher Education 30 Apr. 1999: A16.

Mason, Karen Oppenheim, John L. Czajka, and Sara Arber. "Change in U.S. Women's Sex-Role Attitudes, 1964-1974.” American Sociological Review 41 (1976): 573-96.

Parsad, Basmat, et al. Teacher Preparation and Professional Development: 2000. Natl. Center for Educ. Statistics. NCES 2001-088. June 2001. 14 May $2003<$ http://nces.ed .gov/pubs2001/2001088.pdf>.

Program Rationale. Professional Science Masters. Sloan Science Master's Outreach Initiative. 24 Feb. 2004 <http://www.sciencemasters.com/program_rationale.html>.

Schneider, Alison. "Master's Degrees, Once Scorned, Attract Students and Generate Revenue." Chronicle of Higher Education 21 May 1999: A12.

Schulman, Bruce J. The Seventies: The Great Shift in American Culture, Society, and Politics. New York: Free, 2001.

Woolston, Chris. "Reviving a 'Lesser' Degree in the Sciences." Chronicle of Higher Education 17 June 2003. 18 June 2003 <http://chronicle.com/jobs/2003/06/2003061701c.htm>. 